\title{
Study of Antinociceptive, Antipyretic and Neuropharmacological Activities of Leaf Extracts of Citrus assamensis
}

\author{
Mohammad Shahriar ${ }^{1,2}$, Mohiuddin Ahmed Bhuiyan ${ }^{2}$ and Md. Sohel Rana ${ }^{1}$ \\ ${ }^{1}$ Department of Pharmacy, Jahangirnagar University, Savar, Dhaka, Bangladesh \\ ${ }^{2}$ Phytochemistry Research Laboratory, Department of Pharmacy, University of Asia Pacific \\ Dhaka-1215, Bangladesh
}

(Received: 4 February, 2018; Accepted: 2 April, 2018; Published: 31 July, 2018)

\begin{abstract}
The present study was executed to explore in vivo antinociceptive, antipyretic and neuropharmacological activities of different leaf extracts of Citrus assamensis in Swiss albino mice. C. assamensis leaf extract displayed marked dose dependent antinociceptive potential in the five pain models. All leaf extracts except chloroform $(200 \mathrm{mg} / \mathrm{kg}$ body weight $)$ extract, produced significant $(* * \mathrm{p}<0.01, * * * \mathrm{p}<0.001)$ antinociception against thermal induced pain stimuli in mice at various time points of post treatment in hot plate study compared to the control group. In acetic acid induced writhing assay, methanol $(100 \mathrm{mg} / \mathrm{kg}$ body weight) and chloroform $(200 \mathrm{mg} / \mathrm{kg}$ body weight $)$ extracts showed significant $\left({ }^{*} \mathrm{p}<0.01\right)$ result. In tail immersion test, basal reaction time was found significant $\left({ }^{*} \mathrm{p}<0.01\right)$ in case of ethanol $(100 \mathrm{mg} / \mathrm{kg}$ body weight) and chloroform (200 mg/kg body weight) extracts compared against control. Both the doses of all the extracts exhibited significant $(* * * p<0.001)$ activity in formalin induced paw licking as well as percent inhibition of glutamate induced writhing study. Both the doses of methanol and ethanol extracts showed significant $(* \mathrm{p}<0.05)$ results in decreasing in rectal temperature after $1 \mathrm{hr}$. Higher doses of all the extracts showed significant $(* \mathrm{p}<0.05)$ decrease in duration of immobility in foreed swimming test (FST). The higher dose of ethanol extract $(200 \mathrm{mg} / \mathrm{kg}$ body weight $)$ significantly $(* \mathrm{p}<0.05)$ decreased the rate of movement with time in open field test. The test samples displayed marked antinociceptive potential in all the test procedures and also displayed marked antipyretic and neuropharmacological activities at different test doses.
\end{abstract}

Key words: Antinociceptive, antipyretic, neuropharmacological activity, Citrus assamensis, leaf extracts.

\section{Introduction}

Over the past few decades, strategies of drug discovery have been generally focused on an approach based on single target along with the rapid growth in genetics and molecular biology (Lenardao et al., 2016). Herbal medicines derived from plants are being increasingly utilized to treat a wide variety of diseases and clinical disorders, but relatively little knowledge available about their exact effective doses and mode of action (Saieed et al., 2006). Nowa-days, in many parts of the world traditional medicine replaces conventional medicine because herbal remedies are cost effective, have minimum side effects with reduced health hazards and are easily available in market as compared to synthetic medicines. Many plant extracts possess in vitro and in vivo biological activities, which inspire intense research on their use in traditional medicine (Khandaker et al., 2016; Das et al., 2017a, b; Eshita et al., 2017; Hossain et al., 2016; Laboni et at., 2017a,b; Shahriar et al., 2018b).

Citrus genus belongs to the large family, Rutaceae, which contains 130 genera under seven subfamilies (Lucker et al., 2002). Citrus assamensis locally known as Satkora in Bangladesh, is a small tree, 4.5 to 7.5 meter tall and moderately branched

Correspondence to: Mohammad Shahriar; Mobile: +88-01841844259; E-mail: shahriar@uap-bd.edu 
and thorny plant which is used as medicine by local tribes of Assam, India. Leaves, flowers, and fruits of C. assamensis are used for treating dysentry, indigestion, pimples and intestinal worms (Das et al., 2013). Preliminary phytochemical screening revealed that this plant is rich in alkaloid, phytosterol, phenol, tannin, glycoside, saponin and flavonoids. Pharmacological investigations have demonstrated that $C$. assamensis has antibacterial, thrombolytic, membrane stabilizing, antiinflammatory and antitumor activities (Shahriar et al., 2018b).

As part of our continuing studies on $C$. assamensis, the organic extracts of the leaf extracts of $C$. assamensis was evaluated for antinociceptive and antipyretic activities as well as neurophramacological study in mice for the first time.

\section{Materials and Methods}

Collection, identification and processing of plant sample: Leaves of $C$. assamensis were collected from Jayantapur, Sylhet, Bangladesh (January, 2014) and the plant was taxonomically identified with the help of the National Herbarium of Bangladesh, Mirpur, Dhaka (DACB; Accession Number- 38759). Leaves were sun dried for seven days. The dried leaves were then ground in coarse powder using high capacity grinding machine (Jaipan Designer Mixer Grinder, India) which was then stored in air-tight container in cool, dark and dry plac.

Extraction procedure: The powdered leaves (30 gm) was successively extracted in a soxhlet extractor at elevated temperature using $500 \mathrm{ml}$ of distilled methanol $(40-60)^{\circ} \mathrm{C}$ which was followed by ethanol and chloroform. After extraction all extracts were kept in refrigerator $4^{\circ} \mathrm{C}$ for further investigation.

Experimental animal: Swiss albino mice of either sex, 4-5 weeks of age, weighing between 10$24 \mathrm{gm}$ were collected from ICDDR,B, Dhaka. Animals were maintained under standard environmental conditions and free access to feed and water. The animals were acclimatized to laboratory condition for one week prior to experiments.

\section{In vivo antinociceptive study:}

Hot plate method: The paws of mice are very sensitive to temperature at $55 \pm 0.5{ }^{\circ} \mathrm{C}$, which are not damaging to the skin. The animals were placed on Eddy's hot plate kept at a temperature of $55 \pm$ $0.5^{\circ} \mathrm{C}$. A cut off period of $30 \mathrm{sec}$ (Franzotti et al., 2000), was observed to avoid damage to the paw. Reaction time was recorded when animals licked therefore or hind paws, or jumped at $0,30,60,90$ and $120 \mathrm{~min}$ after oral administration of the samples. The animals of test groups received test samples at the doses of 100 and $200 \mathrm{mg} / \mathrm{kg}$ body weight. Positive control group received standard drug diclofenac sodium at the dose of $10 \mathrm{mg} / \mathrm{kg}$ body weight and saline water.

Acetic acid induced writhing test: The acetic acid writhing test in mice was conducted as described by Khandaker et al. (2016).

Tail immersion test: The tail immersion method was used to evaluate the central mechanism of analgesic activity. Here the painful reactions in animals were produced by thermal stimulus that is by dipping the tip of the tail in hot water. The tail immersion test in mice was conducted as described previously by Barai et al. (2015).

Formalin induced nociception: Animals received $20 \mu \mathrm{l}$ of $2.5 \%$ formalin solution (7\% formaldehyde) made up in saline and injected intraplanetary in the ventral surface of the right hand paw. Animals were observed from 0 to $5 \mathrm{~min}$ (neurogenic phase) and 15-30 min (inflammatory phase) and the time spent licking the injected paw was recorded as indicative of nociception. The animals received methanol, ethanol and chloroform extracts of C. assamensis at 100 and $200 \mathrm{mg} / \mathrm{kg} 1 \mathrm{hr}$ before, with basis of a previous time response curve. Positive control group received standard drug diclofenac sodium at the dose of $10 \mathrm{mg} / \mathrm{kg}$ body weight (Santos et al., 1999).

Glutamate induced nociception: A volume of 20 $\mu \mathrm{l}$ of glutamate $(10 \mu \mathrm{mol} / \mathrm{paw}$ prepared in saline) 
was injected intra-plantarly in the ventral surface of the right hand paw. Animals were observed individually for $15 \mathrm{~min}$ after glutamate injection. The amount of time spends in licking the injected paw was indicated as the nociception. The animals were treated with methanol, ethanol and chloroform extracts of C. assamensis at 100 and $200 \mathrm{mg} / \mathrm{kg} 1 \mathrm{hr}$ before glutamate injection. Positive control group received standard drug diclofenac sodium at the dose of $10 \mathrm{mg} / \mathrm{kg}$ body weight (Beirith et al., 2002).

In vivo antipyretic activity: Antipyretic Activity in mice was performed according to Khandaker et al. (2016).

\section{In vivo neuropharmacological study:}

Hole cross test: The most consistent behavioral change is a hyper emotional response to novel environmental stimuli. The aim of this study was to characterize the emotional behavior of mice using the hole-board test. The hole-cross test in mice was conducted as described by Subhan et al. (2008).

Forced swimming test (FST): Forced swimming test was performed according to Khandaker et al. (2016) at the doses of $100 \& 200 \mathrm{mg} / \mathrm{kg}$ body weight of methanol, ethanol and chloroform extracts respectively.

Open field test (OFT): According to previous work by Eshita et al. (2017), open field test was performed to monitor behavioral responses in mice that were placed in a novel and bright arena, at the doses of $100 \& 200 \mathrm{mg} / \mathrm{kg}$ body weight of methanol, ethanol and chloroform extracts respectively.

Statistical analysis: Data was expressed as mean \pm SEM (Standard error of mean). The results were analyzed statistically by ANOVA followed by Dunnet's test. Results with $\mathrm{p}<0.05, \mathrm{p}<0.01$ and $\mathrm{p}<0.001$ were considered statistically significant.

\section{Results and Discussion}

\section{In vivo antinociceptive study:}

Hot plate test: The hot plate assay is a simple method of the pain reaction in animals by which effectiveness of centrally acting analgesics can be tested by measuring the heat induced pain response. The application of such stimuli evokes a behavioral response which results in the withdrawal of foot which varies inversely with the intensity of the stimulus. In this study, all extracts of the leaves of $C$. assamensis as well as standard diclofenac sodium produced significant $\quad(* * \mathrm{p}<0.01, \quad * * * \mathrm{p}<0.001)$ antinociception against thermal induced pain stimuli in mice at various time points of post treatment while compared with the control group (Table 1). From findings of our study, it was apparent that the lower doses of the extracts have more potent central antinociceptive effect.

Table 1. Effect of different leaf extracts of $C$. assamensis on hot plate test.

\begin{tabular}{|c|c|c|c|c|c|c|}
\hline \multirow{2}{*}{ Treatment } & \multirow{2}{*}{$\begin{array}{c}\text { Dose } \\
(\mathrm{mg} / \mathrm{kg})\end{array}$} & \multicolumn{5}{|c|}{ Response times (Sec.) } \\
\hline & & $0 \mathrm{~min}$ & $30 \mathrm{~min}$ & $60 \mathrm{~min}$ & $90 \mathrm{~min}$ & $120 \mathrm{~min}$ \\
\hline Control & $10 \mathrm{ml} / \mathrm{Kg}$ & $12.02 \pm 0.06$ & $14.27 \pm 0.16$ & $15.20 \pm 0.11$ & $17.11 \pm 0.04$ & $12.40 \pm 0.13$ \\
\hline Diclofenac $\mathrm{Na}$ & 10 & $8.18 \pm 0.03 * * *$ & $9.29 \pm 0.01 * * *$ & $11.36 \pm 0.02 * * *$ & $10.16 \pm 0.05^{* * *}$ & $8.04 \pm 0.02 * * *$ \\
\hline \multirow{2}{*}{$\begin{array}{l}\text { Methanol } \\
\text { extract }\end{array}$} & 100 & $9.18 \pm 0.03^{* * *}$ & $11.21 \pm 0.05^{* * *}$ & $11.55 \pm 0.09 * * *$ & $10.17 \pm 0.11 * * *$ & $9.22 \pm 0.01 * * *$ \\
\hline & 200 & $10.52 \pm 0.03 * * *$ & $12.06 \pm 0.01 * *$ & $12.18 \pm 0.06 * * *$ & $11.49 \pm 0.01 * * *$ & $9.85 \pm 0.03 * * *$ \\
\hline \multirow{2}{*}{ Ethanol extract } & 100 & $10.64 \pm 0.02 * * *$ & $12.27 \pm 0.04 * * *$ & $13.41 \pm 0.14 * * *$ & $11.11 \pm 0.03 * * *$ & $9.87 \pm 0.04 * * *$ \\
\hline & 200 & $12.19 \pm 0.07$ & $14.69 \pm 0.04$ & $14.97 \pm 0.02$ & $16.23 \pm 0.04 * * *$ & $14.44 \pm 0.07 * * *$ \\
\hline \multirow{2}{*}{$\begin{array}{l}\text { Chloroform } \\
\text { extract }\end{array}$} & 100 & $11.57 \pm 0.04 * *$ & $11.83 \pm 0.02 * *$ & $11.98 \pm 0.03 * * *$ & $11.66 \pm 0.09 * * *$ & $10.99 \pm 0.01 * *$ \\
\hline & 200 & $12.02 \pm 0.06$ & $14.27 \pm 0.16$ & $15.20 \pm 0.11$ & $17.11 \pm 0.04$ & $12.40 \pm 0.13$ \\
\hline
\end{tabular}

Values are mean \pm SEM $(\mathrm{n}=6), * *(\mathrm{p}<0.01), * * *(\mathrm{p}<0.001)$ significantly different when compared with the corresponding value of control group, done by independent sample $t$-test 
Acetic acid induced writhing test: In the acetic acid-induced writhing test, the anti-nociceptive effect represented by writhe reduction and elicited by 100 and $200 \mathrm{mg} / \mathrm{kg}$ body weight of $C$. assamensis leaf extract in mice was similar to that of a standard drug, when groups were compared to control (Figure 1). Acetic acid induced abdominal constriction is a standard, simple, and sensitive test for measuring analgesia induced by drugs and chemicals, often advantageous in preclinical investigations of analgesics that represent pain sensation by triggering localized inflammatory response (Khandaker et al., 2016). In the present study methanol and chloroform extracts inhibited no. of writhing compared to standard diclofenac sodium significantly $(* p>0.05)$.

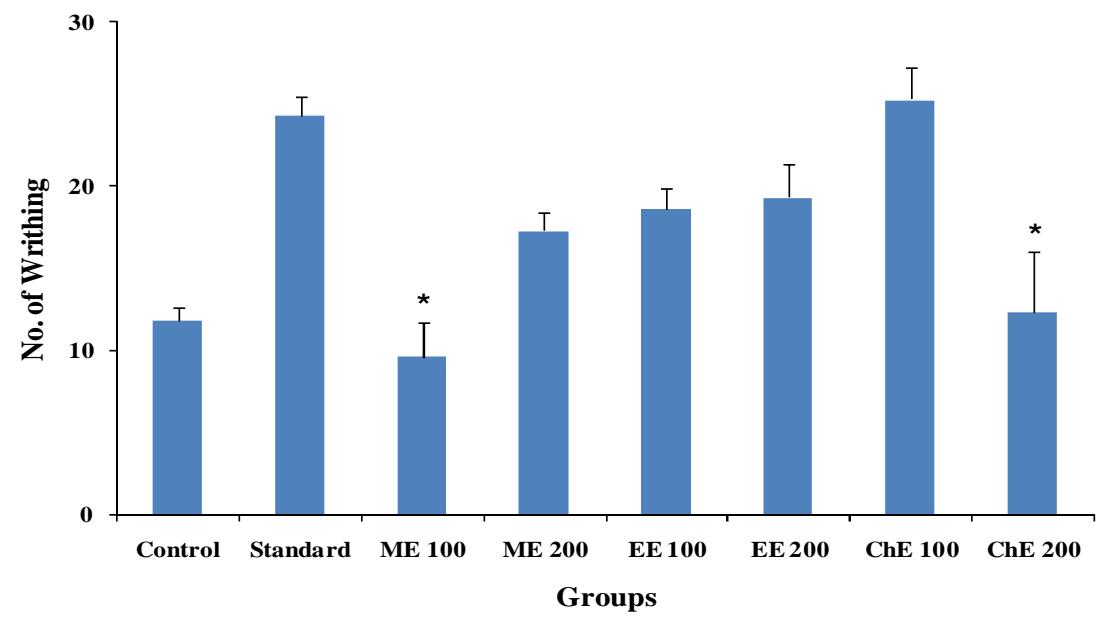

Values are mean \pm SEM $(n=6), *(p<0.05)$ significantly different when compared with the corresponding value of control group, done by independent sample t-test

Figure 1. Effect of $C$. assamensis leaf extracts on acetic acid induced writhing test.

Tail immersion test: In tail immersion method, the heat itself acts as a source of pain whereas the effectiveness of analgesic agents in this pain model is highly correlated with relief of human pain. The different concentrations of methanol, ethanol and chloroform leaf extracts of $C$. assemensis (100 and $200 \mathrm{mg} / \mathrm{kg}$ body weight) and diclofenac sodium (50 $\mathrm{mg} / \mathrm{kg}$ body weight) were administered to mice and observed the basal reaction time in different time intervals (Figure 2). In the present study ethanol and chloroform extracts showed significant $(* \mathrm{p}<0.05)$ analgesic activity compared to standard drug. The basal reaction time increased with increasing the concentrations along with increasing the time.

Formalin induced nociception: Formalin induced pain paradigm is well recommended biphasic procedure for the determination of anti- nociceptive activity. The different concentrations of methanol, ethanol and chloroform leaf extracts of $C$. assamensis has significantly $(* * * \mathrm{p}<0.001)$ decreased the paw licking in both neurogenic and inflammatory phases of formalin induced paw liking test in mice in the present investigation compared to the reference drug diclofenac sodium (Table 2). Chloroform extract ( $200 \mathrm{mg} / \mathrm{kg}$ body weight) caused $32.30 \%$ and $48.72 \%$ inhibition in early phase and late phase, respectively. Considering the inhibitory property of C. assamensis on the second phase of formalin, plant extracts might have anti-inflammatory property.

Glutamate induced nociception: In glutamate induced abdominal writhing test, the test groups treated with 100 and $200 \mathrm{mg} / \mathrm{kg}$ of body weight methanol, ethanol and chloroform leaf extract of $C$. assamensis, exhibited profound significant inhibition 
of the abdominal writhes. Marked activity (36.11\%) was recorded with chloroform extract $(200 \mathrm{mg} / \mathrm{kg}$ body weight), when compared to standard group. The reference standard drug diclofenac sodium produced greater inhibitory effect (61.01\%) as compared to the highest dose of chloroform extract (200 mg/kg body weight), depicted in table 2 . In present study, we observed that the plant extracts inhibited mechanisms of pain, suggesting that $C$. assamensis contain chemical compound which may act as a narcotic analgesic.

In vivo antipyretic test: The results of antipyretic test of $C$. assamensis leaf extracts using Brewer's yeast induced pyrexia in mice have been shown in table 3. In the present study both methanol and ethanol leaf extracts of $C$. assamensis showed a significant $(* \mathrm{p}<0.05)$ decrease in rectal temperature at doses 100 and $200 \mathrm{mg} / \mathrm{kg}$ after $1 \mathrm{hr}$ when compared with the control. However, no significant decrease in mean temperature was noted by chloroform extract when compared with control. But both doses of chloroform extract showed a progressive decline in mean temperature pattern with the increase in the dose (Table 3). Present study suggests a possibly better blockage of prostaglandins biosynthesis or mimicry of paracetamol action by the active principles in the extract.

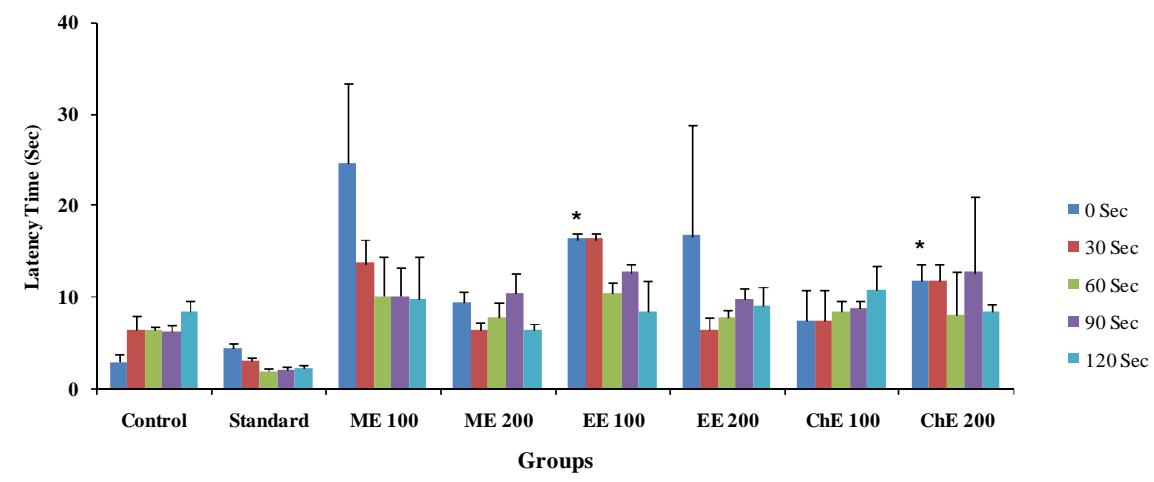

Values are mean \pm SEM $(n=6), *(p<0.05)$ significantly different when compared with the corresponding value of control group, done by independent sample t-test

Figure 2. Effect of $C$. assamensis leaf extracts on tail immersion test.

Table 2. Effect of different leaf extracts of $C$. assamensis on formalin and glutamate induced nociception.

\begin{tabular}{|c|c|c|c|c|c|c|}
\hline \multirow{3}{*}{ Treatment } & \multirow{3}{*}{$\begin{array}{c}\text { Dose } \\
(\mathrm{mg} / \mathrm{kg})\end{array}$} & \multicolumn{4}{|c|}{ Formalin induced nociception } & \multirow{3}{*}{$\begin{array}{c}\text { Glutamate induced } \\
\text { nociception } \\
\% \text { inhibition }\end{array}$} \\
\hline & & \multicolumn{2}{|c|}{ Licking time (Sec) } & \multicolumn{2}{|c|}{$\%$ inhibition } & \\
\hline & & Early phase & Late phase & Early phase & Late phase & \\
\hline Control & 10 & $160 \pm 23.88$ & $65.20 \pm 12.50$ & - & - & - \\
\hline Diclofenac $\mathrm{Na}$ & 10 & $95 \pm 12.75$ & $25.79 \pm 6.22$ & $40.42 \pm 0.25$ & $61.71 \pm 0.38$ & $61.01 \pm 0.49$ \\
\hline \multirow{2}{*}{$\begin{array}{l}\text { Methanol } \\
\text { extract }\end{array}$} & 100 & $150 \pm 18.02$ & $60.20 \pm 9.42$ & $10.41 \pm 0.14 * * *$ & $9.74 \pm 0.10^{* * *}$ & $21.41 \pm 0.45^{* * *}$ \\
\hline & 200 & $155 \pm 20.20$ & $62.32 \pm 15.22$ & $12.38 \pm 0.12 * * *$ & $10.40 \pm 0.14 * * *$ & $20.38 \pm 0.55^{* * *}$ \\
\hline \multirow{2}{*}{ Ethanole } & 100 & $148 \pm 11.32$ & $58.23 \pm 11.42$ & $11.14 \pm 0.04 * * *$ & $8.74 \pm 0.07 * * *$ & $20.96 \pm 0.08 * * *$ \\
\hline & 200 & $155 \pm 21.23$ & $63.03 \pm 8.23$ & $15.55 \pm 0.17 * * *$ & $11.48 \pm 0.11 * * *$ & $22.10 \pm 0.17 * * *$ \\
\hline \multirow{2}{*}{$\begin{array}{l}\text { Chloroform } \\
\text { extract }\end{array}$} & 100 & $116.9 \pm 10.89$ & $39.32 \pm 8.92$ & $29.50 \pm 0.14 * * *$ & $43.60 \pm 0.11 * * *$ & $31.33 \pm 0.23 * * *$ \\
\hline & 200 & $118.8 \pm 8.87$ & $32.50 \pm 5.68$ & $32.30 \pm 0.25 * * *$ & $48.72 \pm 0.06^{* * *}$ & $36.11 \pm 0.07 * * *$ \\
\hline
\end{tabular}

Values are mean \pm SEM $(\mathrm{n}=6), * * *(\mathrm{p}<0.001)$ significantly different when compared with the corresponding value of standard group, done by independent sample $t$-test 
Table 3. Effect of leaf extracts of $C$. assamensis in brewer's yeast induced pyrexia in mice.

\begin{tabular}{lcccccc}
\hline \multirow{2}{*}{ Treatment } & $\begin{array}{c}\text { Dose }(\mathrm{mg} / \mathrm{kg}) \\
\text { body weight }\end{array}$ & \multirow{2}{*}{$\begin{array}{c}\text { Normal temp } \\
\left({ }^{\circ} \mathrm{F}\right)\end{array}$} & $\begin{array}{c}\text { Temp 18 hours } \\
\text { after Brewer's }\end{array}$ & \multicolumn{3}{c}{ Temperature after doses $\left({ }^{\circ} \mathrm{F}\right)$} \\
\cline { 5 - 7 } & & & yeast inj. $\left({ }^{0} \mathrm{~F}\right)$ & $1 \mathrm{hr}$ & $2 \mathrm{hr}$ & $3 \mathrm{hr}$ \\
\hline $0.9 \% \mathrm{NaCl}$ & $1 \mathrm{ml} / 100 \mathrm{gm} \mathrm{b.w}$ & $97.82 \pm 0.12$ & $99.17 \pm 0.18$ & $95.62 \pm 0.12$ & $95.08 \pm 0.01$ & $95.95 \pm 0.17$ \\
Paracetamol & 50 & $97.14 \pm 0.14$ & $98.36 \pm 0.08$ & $93 \pm 0.22$ & $93.2 \pm 0.23$ & $93.78 \pm 0.59$ \\
Methanol & 100 & $95.25 \pm 0.11$ & $96.3 \pm 0.13$ & $96.2 \pm 0.15^{*}$ & $96.5 \pm 0.11^{*}$ & $96.42 \pm 0.10$ \\
extract & 200 & $96 \pm 0.0 .14$ & $97.35 \pm 0.46$ & $97.37 \pm 0.39^{*}$ & $96.62 \pm 0.41^{*}$ & $97.45 \pm 0.30$ \\
Ethanol & 100 & $96.1 \pm 0.0 .58$ & $96.92 \pm 0.53$ & $96.35 \pm 0.51^{*}$ & $96.8 \pm 0.48$ & $96.52 \pm 0.47$ \\
extract & 200 & $94.55 \pm 0.07$ & $96.12 \pm 0.09$ & $95.65 \pm 0.09^{*}$ & $94.55 \pm 0.13 *$ & $95.2 \pm 0.12$ \\
Chloroform & 100 & $93 \pm 0.09$ & $94.17 \pm 0.14$ & $93.87 \pm 0.19$ & $92.8 \pm 0.16$ & $93.37 \pm 0.13$ \\
extract & 200 & $93.05 \pm 0.3$ & $94.42 \pm 0.30$ & $94.05 \pm 0.28$ & $93.15 \pm 0.29$ & $93.82 \pm 0.28$ \\
\hline
\end{tabular}

Values are mean \pm SEM $(\mathrm{n}=6), *(\mathrm{p}<0.05)$, significantly different when compared with the corresponding value of control group, done by independent sample $t$-test

\section{In vivo neuropharmacological study:}

Hole cross test: To acquire evocative results regarding the sedative effects of methanol, ethanol and chloroform leaf extracts of $C$. assamensis by recording spontaneous locomotor activity of mice, hole cross method was implemented. Mice treated with methanol, ethanol and chloroform leaf extracts of C. assamensis at two doses $(100 \mathrm{mg} / \mathrm{kg} \& 200$ $\mathrm{mg} / \mathrm{kg}$ ) showed dose dependent reduction in the locomotor activity which was comparable with standard drug diazepam. In case of control group, negligible variation in number of holes crossed from one chamber to another by mice was observed from 30 to 60 minute whereas groups treated with leaf extract at the above mentioned doses showed significant decrease of movement from their primary value at 90 minute (Table 4). Extracts of $C$. assamensis leaf decreased locomotor activity indicating its CNS depressant activity.

Forced swimming test (FST): Forced swimming test (FST) was performed to evaluate anti-depressant effect of leaf extracts of $C$. assemensis on mice. The main advantages of this procedure lie in its relatively easy operation and fast results. This test can also differentiate between drugs that are not aimed for the treatment of depression such as benzodiazepines, which have been shown to possess anti-anxiety effects. In the present study methanol, ethanol and chloroform extracts $(200 \mathrm{mg} / \mathrm{kg}$ body weight), showed significant $(* \mathrm{p}<0.05)$ decrease in duration of immobility compared to control (Figure 3). Among the three extracts and standard, chloroform extract was found to be more effective.

Table 4. Effect of leaf extracts of $C$. assamensis in hole cross test in mice.

\begin{tabular}{lccccc}
\hline \multirow{2}{*}{ Group } & $\begin{array}{c}\text { Dose }(\mathrm{mg} / \mathrm{kg}) \\
\text { body weight }\end{array}$ & $0 \mathrm{~min}$ & $30 \mathrm{~min}$ & $60 \mathrm{~min}$ & $90 \mathrm{~min}$ \\
\cline { 3 - 6 } & - & $18.40 \pm 0.39$ & $10.85 \pm 0.32$ & $10.45 \pm 0.21$ & $6.95 \pm 0.66$ \\
Control & 50 & $6.60 \pm 0.21$ & $5.60 \pm 0.22$ & $8.20 \pm 0.21$ & $7.21 \pm 0.78$ \\
Standard & 100 & $7.23 \pm 0.58$ & $5.32 \pm 0.45$ & $8.45 \pm 0.45$ & $5.21 \pm 0.41$ \\
Methanol & 200 & $9.31 \pm 0.25$ & $7.85 \pm 0.58$ & $8.74 \pm 0.42$ & $6.54 \pm 0.24$ \\
Extract & 100 & $8.32 \pm 0.78$ & $5.42 \pm 0.55$ & $9.25 \pm 0.21$ & $7.52 \pm 0.11$ \\
Ethanol & 200 & $7.51 \pm 1.23$ & $6.42 \pm 0.21$ & $9.74 \pm 0.22$ & $8.25 \pm 0.34$ \\
Extract & 100 & $6.89 \pm 0.52$ & $5.10 \pm 0.50$ & $7.41 \pm 0.21$ & $5.21 \pm 0.17$ \\
Chloroform & 200 & $6.65 \pm 1.23$ & $4.32 \pm 0.52$ & $7.12 \pm 0.24$ & $5.23 \pm 0.13$ \\
Extract & & & & &
\end{tabular}

Values are mean $\pm \operatorname{SEM}(n=6)$ 


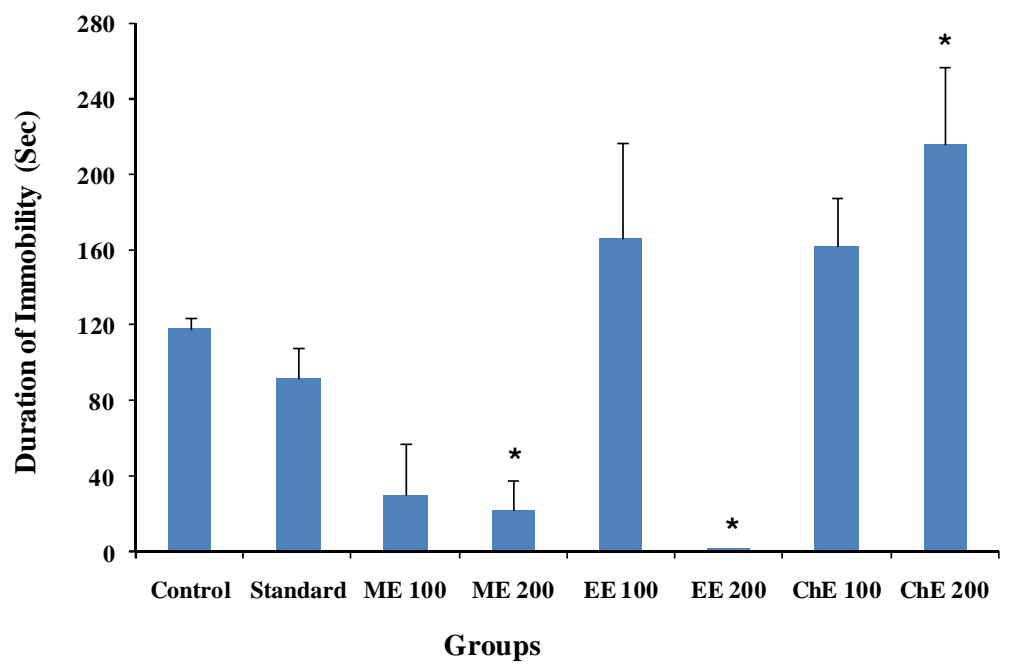

Values are mean \pm SEM $(\mathrm{n}=6), *(\mathrm{p}<0.05)$ significantly different when compared with the corresponding value of control group, done by independent sample $t$-test

Figure 3. Effect of different leaf extracts of $C$. assamensis in forced swimming test.

A)

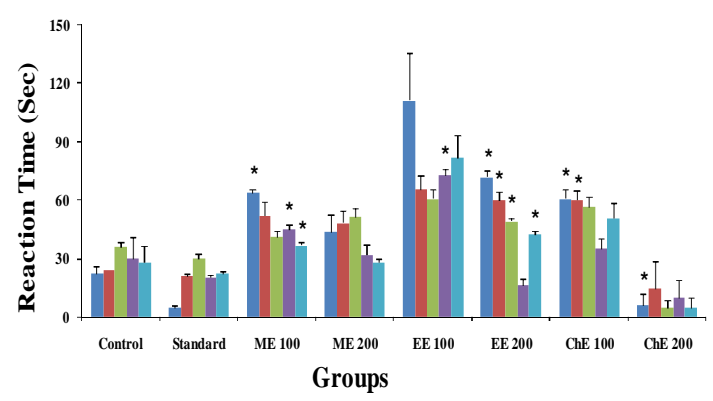

C)

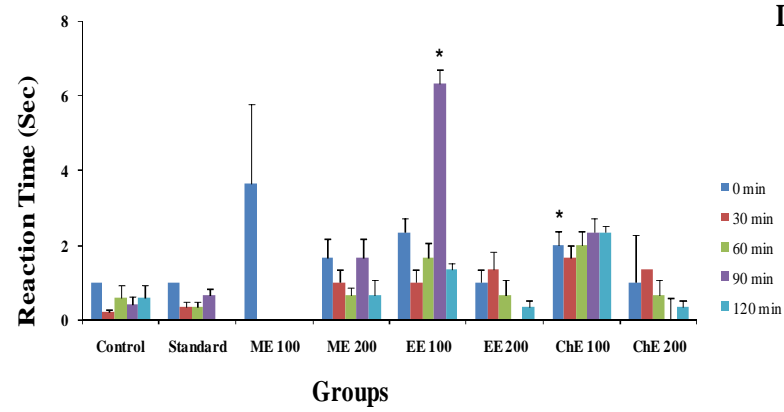

B)

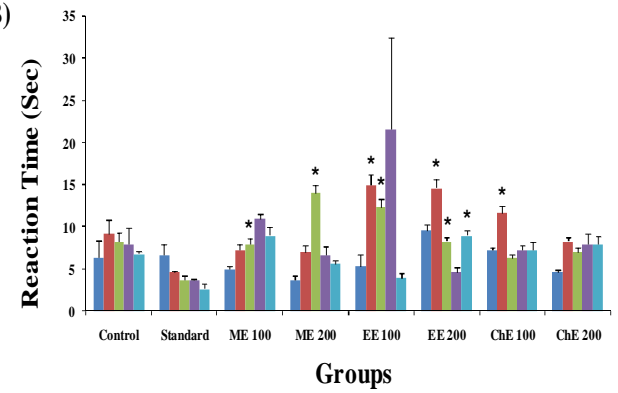

D)

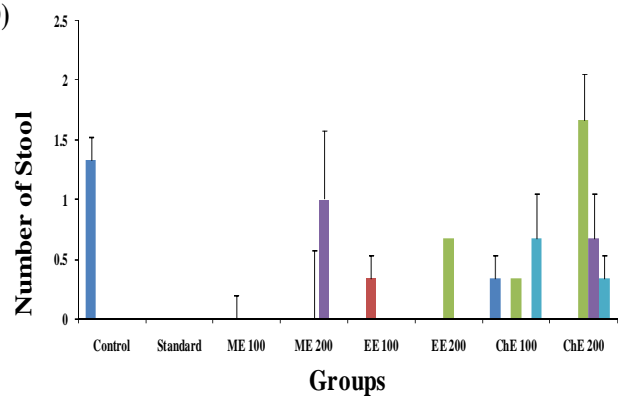

Values are mean \pm SEM $(n=6), *(p<0.05)$ significantly different when compared with the corresponding value of control group, done by independent sample $t$-test

Figure 4. Graphical representation of the effects of different leaf extracts of $C$. assamensis in open field test (A: movement,

B: standing, C: center, D: stool).

Open field test (OFT): The crude methanol, ethanol and chloroform extracts of $C$. assamensis were subjected to assay for open field test following standard protocol and the obtained results were represented in figure 4 (A-D). In the open-field test methanol $(100 \mathrm{mg} / \mathrm{kg})$, ethanol (100 and $200 \mathrm{mg} / \mathrm{kg}$ ) and chloroform $(100 \mathrm{mg} / \mathrm{kg}$ and $200 \mathrm{mg} / \mathrm{kg})$ extracts showed significant results in case of movement and 
standing assay as compared to control group (Figure $4 \mathrm{~A} \& 4 \mathrm{~B})$. The results of the present investigation indicated that the extracts significantly decreased the locomotor activity as shown by the results of the open field tests. In the present study it was also observed that the extracts decreased the frequency of standing, entrance into center and stool count compared with control and standard. Therefore, the use of $C$. assamensis in folkloric medicine may be due to its CNS action validated by our findings. However, further investigation is necessary to determine the exact phytoconstituents and mechanism of action that are responsible for the biological activities of the extracts of $C$. assamensis.

\section{Conclusion}

Biological investigations carried out on $C$. assamensis plant in this study mainly focusing on the leaf of the plant but those are considered to be preliminary. As a result more elaborated research may be necessary to reach concrete conclusion about the finding of the present study. On the basis of above results and available reports, all three leaf extracts of C. assamensis showed potent antinociceptive, antipyretic and neuropharmacological activities. However, isolating new bioactive compounds and evolution of their extracts, mode of action and chronic toxicity profile might be the next steps to be followed to eventually find new lead compounds. The plant can be further screened against various diseases in order to find out its unexplored efficacy and can be a potential source of chemically interesting and biologically important drug candidates.

\section{References}

Barai, L., Akhter, R., Aziz, U., Ali, M., and Shahriar, M. 2015. In vivo pharmacological investigations of Citrus hystrix. Int. J. Pharm. 5, 1149-1154.

Beirith, A., Santos, A. R. S., and Calixto, J. B. 2002. Mechanisms underlying the nociception and paw oedema caused by injection of glutamate into the mouse paw. Brain Res. 924, 219-228.
Das, A. J., Kumar, R., Athar, M., Rawat, D. S., Kumar, M., Khan, M. A., and Prakash, J. 2013. Ethno medicinal study of threatened plants of Sonitpur district in Assam, North East India. Int. Res. J. Pharm. 4, 146-149.

Das, S., Akhter, R., Huque, S., Anwar, R., Das, P., Tanni, K. A., and Shahriar, M. 2017a. In vitro anthelmintic activity of leaf extracts of four different types of Calamus Species. Pharm. Pharmacol. Int. J. 5, 00118.

Das. S., Akhter, R., Khandaker, S., Huque, S., Das, P., Anwar, M. R., Tanni, K. A., Shabnaz, S., and Shahriar, M. 2017b. Phytochemical screening, antibacterial and anthelmintic activities of leaf and seed extracts of Coixlacryma jobi L. J. Coast. Life Med. 5, 360-364.

Eshita, N. J., Das, S., Akhter, A., Huque, S., Bhuiyan, M. A., and Shahriar, M. 2017. Exploration of in vitro antioxidant, thrombolytic activity, neuropharmacological and anti-pyretic activity of leaf extracts of Hoya parasitica (Wall.). Int. J. Cur. Adv. Res. 6, 3776-3782.

Franzotti, E. M., Santos, C. V. F., Rodrigues, H. M. S. L., Mourao, R. H. V., Andrade, M. R., and Antoniolli, A. R. 2000. Anti-inflammatory, analgesic activity and acute toxicity of Sida cordifolia L. (Malva-branca). J. Ethnopharmacol. 72, 273-278.

Hossain, M. S., Niloy, S. A., Hosen, A., Islam, M. A. U., Islam, Z., Das, S., Hassan, M. A., Islam, A. F. M. M., and Rana, M. S. 2016. Antioxidant activities and HPLC-DAD based phenolic content determination of Bauhinia scandens. Bri. J. Pharm. Res. 14, 1-9.

Khandaker, S., Das, S., Opo, F. A. D. M., Akhter, R., and Shahriar, M. In vivo pharmacological investigations of the crude extracts of Calamus viminalis (L.). 2016. J. Pharmacogn. Phytochem. 5, 263-269.

Laboni, F. R., Mahmud, S., Karim, S., Das, S., and Shahriar, M. 2017b Biological investigations of different leaf extracts of Litsea liyuyingi (FamilyLauraceae). IOSR J. Pharm. Biol. Sci. 12, 08-17.

Laboni, F. R., Sultana, T., Kamal, S., Karim, S., Das, S., Harun-Or-Rashid, M., and Shahriar, M. 2017 a. Biological investigations of the ethanol extract of the aerial part (leaf) of Coccinia grandis L. J. Pharmacogn. Phytochem. 6, 134-138.

Lenardão, E. J., Savegnago, L., Jacob, R. G., Victoria, F.N., and Martinez, D. M. 2016. Anti-nociceptive effect of essential oils and their constituents: an update review. J. Braz. Chem. Soc. 27, 435-474. 
Lucker, J., Tamer, M. K., Schwab, W., Verstappen, F. W. A., Plas, L. H. W. V., Bouwmesster, H. J., and Verhoeven, H. A. 2002. Monoterpene biosynthesis in lemon (Citrus limon). Eur. J. Biochem. 269, 31603171.

Saieed, P., Reza, R. M., Abbas, D., Seyyedali, R., and Aliasghar, H. 2006. Inhibitory effects of Ruta graveolens L. extract on guinea pig liver aldehyde oxidase. Chem. Pharm. Bull. 54, 9-13.

Santos, A. R. S., Miguel, O. G., Yunes, R. A., and Calixto, J. B. 1999. Antinociceptive properties of the new alkaloid, cis-8, 10-di-Npropyllobelidiolhydrochloride dihydrate isolated from Siphocam pylusverticillatus: evidence for the mechanism of action. J. Pharmacol. Exp. Ther. 289, 417-426.
Shahriar, M., Bhuiyan, M. A., and Rana, M. S. 2018a. Characterization of phytoconstituents and exploration of antioxidant and free radical scavanging activities of Citrus assamensis leaf. Dhaka Univ. J. Pharm. Sci. 17, 29-36.

Shahriar, M., Bhuiyan, M. A., and Rana, M. S. screening of antibacterial, thrombolytic, membrane stabilizing, anti-inflammatory and antitumor activity of Citrus assamensis leaf extracts. 2018b. J. Sci. Res. 10, 195210.

Subhan, N., Alam, M. A., Ahmed, F., Shahid, I. J., Nahar, L., Sarker, S. D. 2008. Bioactivity of Excoecaria agallocha. Braz. J. Pharmacogn. 18, 521-526. 